\title{
Utilization of cinnamon Cinnamomum burmannii leaves and shrimp head in the feed on growth performance of catfish Pangasianodon hypopthalmus
}

\section{Penggunaan daun Cinnamomum burmannii dan kepala udang dalam pakan terhadap kinerja pertumbuhan ikan patin Pangasianodon hypopthalmus}

\author{
Suclyadi Dairun ${ }^{*}$, Mia Setiawati', Muhammad Agus Suprayudi', Nur Bambang Priyo \\ Utomo $^{1}$ \\ ${ }^{1}$ Department of Aquaculture, Faculty of Fisheries and Marine Science, Bogor Agricultural University, \\ Dramaga, Bogor, West Java 16680 \\ *E-mail: suclyadidairun@gmail.com
}

(Received February 22, 2017; Accepted May 17, 2018)

\begin{abstract}
Catfish farming has confronted with the problem of slow growth to reach the fillet size and less tender of fish fillets. This study aimed to investigate the effect of cinnamon leaf flour and shrimp head flour in formulated diets on growth of catfish Pangasianodon hypopthalamus. Catfish with an initial weight of $207.04 \pm 2.70 \mathrm{~g} / \mathrm{fish}$ reared in 12 cages with a dimension of $2 \times 1 \times 1.5 \mathrm{~m}^{3}(\mathrm{~L} \times \mathrm{W} \times \mathrm{H})$ and its fish density was 15 fishes for 60 days. Fish were fed with following experimental diets: (1) Control; (2) cinnamon leaf (1\%) (CL); (3) 45\% of protein source from shrimp head (SH); (4) CL+SH mix. The fishes fed twice a day with feeding rate $3.5 \%$ of fish biomass. The study found that the use of cinnamon leaf and shrimp head increased the specific growth rate $1.67-1.70 \% /$ day, the feed efficiency 57.55-57.67\%, and protein retention 55.61\% compared to its control $(\mathrm{P}<0.05)$. Triglyceride level, cholesterol, and blood HDL were 416.00-524.05 mg/dL, 139.65-156.68 mg/dL, 73.18-103.70 mg/dL ( $>>0.05)$, respectively. HSI value ranged between $0.3-1.9 \%$ compared to its control $(\mathrm{P}<0.05)$.
\end{abstract}

Keywords: Cinnamomum burmannii, feed, growth, Pangasianodon hypopthalmus, shrimp head.

\section{ABSTRAK}

Budidaya ikan patin dihadapkan pada permasalahan pertumbuhan dan kualitas daging yaitu pertumbuhan yang lambat untuk mencapai ukuran fillet serta tekstur daging kurang kompak. Tujuan penelitian ini adalah untuk menguji pengaruh penggunaan tepung daun kayu manis dan tepung kepala udang dalam pakan terhadap pertumbuhan ikan patin Pangasianodon hypopthalmus. Ikan patin dengan bobot 207,04 $\pm 2,70$ g/ekor dipelihara selama 60 hari di hapa sebanyak 12 buah (berukuran $2 \times 1 \times 1,5 \mathrm{~m} 3$ ) dengan padat tebar 15 ekor/jaring. Ikan diberi pakan perlakuan yang terdiri dari: (1) Kontrol; (2) daun kayu manis 1\% (DKM); (3) 45\% sumber protein dari kepala udang (TKU); dan (4) campuran DKM+TKU. Pemberian pakan sebanyak 2 kali sehari dengan feeding rate 3,5\% dari biomassa ikan. Hasil dari penelitian penggunaan daun kayu manis dan kepala udang meningkatkan nilai laju pertumbuhan harian 1,67-1,70\%/day, efisiensi pakan 57,55-57,67\% dan retensi protein 55,61\% dibanding kontrol $(\mathrm{P}<0,05)$. Kadar trigliserida, kolesterol, dan HDL darah berturut-turut adalah 416,00-524,05 mg/dL, 139,65-156,68 mg/dL, 73,18-103,70 mg/dL ( $\mathrm{P}>0,05)$. Nilai HSI ikan patin berkisar antara 0,3-1,9\% dibanding kontrol $(\mathrm{P}<0,05)$.

Kata kunci: Cinnamomum burmannii, kepala udang, pakan, Pangasianodon hypopthalmus, pertumbuhan. 


\section{INTRODUCTION}

Indonesian catfish production was estimated at 500,000-600,000 tonnes per year, with Pangasianodon hypothalamus as the main cultivated species (FAO, 2015). Nonetheless, Indonesian Pangasius farming is still lower in both productivity and quality of flesh. In order to meet the needs of the exported catfish fillet, the flesh quality of the fish must be improved. Thus, several attempts have been implemented to improve the growth performance and the flesh quality of catfish.

Cinnamomum burmannii leaves and shrimp head have been included in the feed formulation for improving the growth performance and the flesh quality of catfish. The cinnamon leaf contains bioactive compounds, such as tannins, saponins, flavonoids, and cinnamaldehyde, which can serve as anti-hypercholesterolemia, antioxidants, also act as insulin mimesis that is to increase cellular glucose metabolism (Gruenwald et al., 2010). Several studies have been conducted to improve the growth performance and the flesh quality of the fish by using cinnamon leaves flour. Setiawati et al. (2014) reported that protein retention from supplementation of cinnamon leaves in the fish diet was 1.5 times higher, while the feed efficiency was twice higher. The body fat of catfish decreased to be $30 \%$, and the flesh texture observed was more compact. Furthermore, the inclusion of $0.1 \%$ and $1 \%$ cinnamon leaves flour extract in the diet resulted in increases in specific growth rate (SGR; 24-29\%/day), feed efficiency (FE; 40-46\%), and protein retention (PR; 56-67\%) of the culture species (Setiawati et al., 2016).

Shrimp head has $45.62 \%$ of protein, $6.62 \%$ of fat, 14.88 of crude fibre, and $10.17 \%$ of moisture content (Research Center Laboratory for Biological Resources and Biotechnology, 2016). Shrimp waste has been identified as the source of chitin (20-30\% chitin on a dry basis of dry weight). Chitin in shrimp shells binds to calcium carbonate, proteins, and lipids (Pamungkas, 2007). Chitosan has the ability to prevent cholesterol absorption, so that an elevated cholesterol level in the blood can be prevented (Muflihunna \& Mu'nisa, 2010).

Several studies have been done on the inclusion of shrimp head meal in the fish feed formulation. Shrimp head meal in the fish diet increased daily growth rate (DGR), feed efficiency (FE), protein efficiency ratio (PER), survival and protein content of the fish (Fall et al., 2012; Diop et al., 2013). Moreover, Melati et al. (2012) stated that shrimp head meal could be used to replace fishmeal protein up to $45 \%$ in the feed formulation for catfish in hatcheries. Cinnamon leaves and shrimp heads have a content that can improve the performance of metabolism and growth of catfish. The utilization of cinnamon leaves and shrimp heads in raw materials feed can decrease feed production cost.

This study aimed to analyze and evaluate the effects of cinnamon leaves meal and shrimp head meal in the formulated diet on the growth performance of catfish during 60 days of feeding trial.

\section{MATERIALS AND METHODS}

\section{Preparation of experimental materials}

Twelve units of the tank $(2 \times 1 \times 1.5 \mathrm{~m})$ with nets were used for the rearing of catfish in this study. The experimental animals used in this study were 180 catfish with an average weight of $207.04 \pm$ $2.70 \mathrm{~g} /$ individual. Cinnamon leaves and shrimp head (carapace) were prepared for the fish diet formulation.

Cinnamon leaves were taken from Jambi Province. Cinnamon leaves dried in an oven with a temperature of $40{ }^{\circ} \mathrm{C}$, then it was grounded using a grinding machine, those were then sieved to produce fine cinnamon leaves meal. The results of the proximate analysis and the analysis of phytochemical compounds of cinnamon leaves contained $9.89 \%$ of protein, $2.44 \%$ of fat, $38.94 \%$ of crude fibre, $4.43 \%$ of ash, $44.29 \%$ of NFE (nitrogen-free extract), $1.80 \%$ of flavonoids, $2.74 \%$ of tannins, $2.32 \%$ of saponins, and cinnamaldehyde content in cinnamon leaves meal was $59.46 \%$. Shrimp's wastes (heads or carapaces) were obtained from shrimp waste processing. Shrimp's waste cleaned and dried in an oven at $40{ }^{\circ} \mathrm{C}$. That shrimp's wastes were grounded to produce refined meal. The results of the proximate analysis of shrimp's waste showed that the shrimp's waste contained $50.13 \%$ of protein, $7.00 \%$ of fat, $16.33 \%$ of crude fibre, $20.71 \%$ of ash, and $5.82 \%$ of NFE.

\section{Feed formulation of experimental diets}

The experimental diets used in this study was illustrated in Table 1. Cinnamon leaves meal (1\%) was incorporated into the experimental diets (Setiawati et al., 2014; Setiawati et al., 2016), and the protein of fishmeal was replaced by $45 \%$ shrimp head meal (Melati et al., 2012). 
Table 1. Experimental feed formulation

\begin{tabular}{lcccc}
\hline \multirow{2}{*}{ Materials } & \multicolumn{4}{c}{ Composition (\%) } \\
\cline { 2 - 5 } & Control & CL & SH & CL+SH \\
\hline Cinnamon leaves meal & 0.00 & 1.00 & 0.00 & 1.00 \\
Shrimp heads meal & 0.00 & 0.00 & 5.55 & 5.55 \\
Fish meal & 10.00 & 10.00 & 5.50 & 5.50 \\
Meat bone meal & 10.50 & 10.50 & 10.50 & 10.50 \\
Palm oil meal & 15.50 & 15.50 & 15.50 & 15.50 \\
Bean flour & 12.50 & 12.50 & 12.50 & 12.50 \\
Pollard & 19.50 & 19.50 & 19.50 & 19.50 \\
Rice bran & 20.00 & 19.00 & 18.95 & 17.95 \\
Sago flour & 4.00 & 4.00 & 4.00 & 4.00 \\
Oil* & 3.00 & 3.00 & 3.00 & 3.00 \\
Premix & 5.00 & 5.00 & 5.00 & 5.00 \\
\hline Protein (\%) & 25.62 & 24.30 & 23.78 & 25.36 \\
Fat (\%) & 7.84 & 7.08 & 7.38 & 7.90 \\
Fibre (\%) & 15.50 & 15.18 & 20.01 & 16.86 \\
NFE (\%) & 35.31 & 36.67 & 31.84 & 33.75 \\
GE (kcal/kg) & 3944.00 & 3963.00 & 3917.00 & 3900.00 \\
C/P (kcal/g) & 15.40 & 16.31 & 16.47 & 15.38
\end{tabular}

*) The mixed of fish oil and soybean oil at a ratio of 1:1, CL = cinnamon leaves, $\mathrm{SH}=$ shrimp head meal, NFE = nitrogen-free extract, $\mathrm{GE}=$ gross energy $($ protein $5.6 \mathrm{kcal} / \mathrm{g}$, fat $9.4 \mathrm{kcal} / \mathrm{g}$; carbohydrate $4.1 \mathrm{kcal} / \mathrm{g}$ (Watanabe, 1988), $\mathrm{C} / \mathrm{P}=$ ratio of energy protein feed.

This study used four diets as treatments with three replications of each included control (without the cinnamon leaves and shrimp heads in the diet), CL (cinnamon leaves supplemented diet), SH (shrimp head supplemented diet), and CL+SH (cinnamon leaves and shrimp heads supplemented diet).

Raw materials for feed formulation was grounded and mixed by using a mixer in a proportion as mentioned in Table 1 . The mixture was made to be a dough, and it was molded into pellets with a size of $3 \mathrm{~mm}$ by using pellet machine. The feed was dried using an oven at 40 ${ }^{\circ} \mathrm{C}$ for 24 hours.

\section{Pisciculture}

The acclimation period of the fish was conducted for a week. During the acclimation period, the fish fed with the control diet twice a day. The fish satiated for 24 hours before the experiment started. The fish samples were taken to determine the initial weight, the proximate analysis of the fish body, flesh, liver, and hepatosomatic index. The fishes were reared in nets with a stocking density of 15 individuals/ net. The fish were fed twice a day (09:00 am and $05: 00 \mathrm{pm}$ ) with feeding rate of $3.5 \%$ of the average biomass in each net for 60 days.

\section{Experimental procedure}

Fish was randomly weighed for each treatment to obtain the weight of the fish, blood sampling, and the proximate analysis of the fish body and liver. Blood was taken from three fishes of each replication in vena caudal by using an anticoagulant syringe (3.8\% sodium citrate). The blood was transferred into a microtube, then centrifuged at 10,000 rpm for 5 minutes. Plasma blood supernatant was taken to transfer into a new microtube and stored in a freezer at $-20{ }^{\circ} \mathrm{C}$ which would be used for the analysis of cholesterol, triglycerides, and HDL.

\section{Experimental parameters}

Experimental parameters were feed intake (FI), specific growth rate (SGR) (Guo et al., 2012), feed efficiency (FE) (Watanabe, 1988), protein retention (PR) (Watanabe, 1988), fat retention (FR) (Watanabe, 1988), and survival. Testing of liver included: water content, fat, glycogen, and hepatosomatic index. Blood biochemical parameters included: cholesterol, triglycerides, and HDL (high-density lipoprotein). Cholesterol and triglycerides were measured by the enzymatic colorimetric method (CHOD-PAP/cholesterol oxidase phenol amino antipyrine). Cholesterol 
ester was hydrolyzed to release cholesterol and subsequently oxidized. The colorimetric indicator was quinone imine that produced from 4-amino antipyrine and phenol by hydrogen peroxide by catalyst peroxidase.

\section{Data analysis}

Statistical analysis was performed using Microsoft Office Excel 2010 and SPSS 22. Significant differences among treatments were determined through ANOVA and were further tested through Duncan's test at $\mathrm{p}=0.05$. All data were analyzed statistically, except cholesterol, triglycerides, and HDL data that were analyzed descriptively.

\section{RESULTS AND DISCUSSIONS}

\section{Results}

The growth performance of catfish in this study included initial weight (IW), final weight $(\mathrm{FW})$, feed intake (FI), specific growth rate (SGR), feed efficiency (FE), protein retention (PR), lipid retention (LR), and survival rate showed in Table 2. The weight of fish increased after 60 days of the feeding trial. However, there were no significant differences $(\mathrm{P}>0.05)$ in feed intake. SGR, FE, and PR of catfish, fed CL and $\mathrm{CL}+\mathrm{SH}$ were significantly different $(\mathrm{P}<0.05)$ to the control. The lipid retention value of $\mathrm{SH}$ was not significantly different $(\mathrm{P}>0.05)$ from $\mathrm{CL}$ and $\mathrm{CL}+\mathrm{SH}$. Nonetheless, it was significantly different $(\mathrm{P}<0.05)$ from the control.

The results of the chemical analysis of catfish liver illustrated in Table 3. The water content in the CLSH treatment was significantly different $(\mathrm{P}<0.05)$ from the control. In the other hand, the content of fat and glycogen of liver was not significantly different $(\mathrm{P}>0.05)$ from control. Hepatosomatic index value in $\mathrm{SH}$ was significantly different $(\mathrm{P}<0.05)$ from the control. The results of the catfish blood biochemical test (Table 4) showed that triglyceride values ranged from $416.00-524.05 \mathrm{mg} / \mathrm{dL}$, cholesterol was $139.65-156.68 \mathrm{mg} / \mathrm{dL}$, and blood HDL was $73.18-103.70 \mathrm{mg} / \mathrm{dL}$.

\section{Discussion}

During the 60-day-feeding-trial, the feed intake (FI) of catfish for both treatments and

Table 2. Initial weight (IW), final weight (FW), feed intake (FI), specific growth rate (SGR), feed efficiency (FE), protein retention (PR), fat retention (FR), and survival of catfish during the 60-day-feeding-trial.

\begin{tabular}{lcccc}
\hline \multirow{2}{*}{ Parameters } & \multicolumn{4}{c}{ Treatments } \\
\cline { 2 - 5 } & Control & CL & SH & CL+SH \\
\hline IW (g) & $208.73 \pm 1.80^{\mathrm{a}}$ & $204.44 \pm 2.97^{\mathrm{a}}$ & $208.36 \pm 1.69^{\mathrm{a}}$ & $206.62 \pm 2.83^{\mathrm{a}}$ \\
FW (g) & $540.73 \pm 4.63^{\mathrm{a}}$ & $558.00 \pm 1.75^{\mathrm{c}}$ & $548.32 \pm 2.94^{\mathrm{b}}$ & $572.40 \pm 2.44^{\mathrm{d}}$ \\
FI (g) & $630.82 \pm 7.96^{\mathrm{a}}$ & $614.42 \pm 9.27^{\mathrm{a}}$ & $632.27 \pm 3.13^{\mathrm{a}}$ & $630.35 \pm 3.82^{\mathrm{a}}$ \\
SGR (\%/day) & $1.59 \pm 0.02^{\mathrm{a}}$ & $1.67 \pm 0.02^{\mathrm{b}}$ & $1.61 \pm 0.01^{\mathrm{a}}$ & $1.70 \pm 0.02^{\mathrm{b}}$ \\
FE (\%) & $52.32 \pm 1.07^{\mathrm{a}}$ & $57.55 \pm 0.88^{\mathrm{b}}$ & $53.50 \pm 0.63^{\mathrm{a}}$ & $57.67 \pm 0.62^{\mathrm{b}}$ \\
PR (\%) & $44.07 \pm 1.17^{\mathrm{a}}$ & $53.20 \pm 0.84^{\mathrm{c}}$ & $46.86 \pm 1.38^{\mathrm{b}}$ & $55.61 \pm 2.11^{\mathrm{c}}$ \\
LR (\%) & $98.63 \pm 1.94^{\mathrm{c}}$ & $94.05 \pm 1.61^{\mathrm{bc}}$ & $89.85 \pm 2.51^{\mathrm{ab}}$ & $88.56 \pm 4.07^{\mathrm{a}}$ \\
Survival (\%) & $97.78 \pm 3.85^{\mathrm{a}}$ & $100.00 \pm 0.00^{\mathrm{a}}$ & $95.56 \pm 3.85^{\mathrm{a}}$ & $97.78 \pm 3.85^{\mathrm{a}}$ \\
\hline Note: All data
\end{tabular}

Note: - All data were shown as the mean \pm standard deviation

- Different superscripts on the same row indicated significant difference $(\mathrm{P}<0.05)$

Table 3. Analysis of catfish liver after 60 days of the feeding trial.

\begin{tabular}{lcccc}
\hline \multirow{2}{*}{ Parameters } & \multicolumn{4}{c}{ Experimental feed treatments } \\
\cline { 2 - 5 } & Control & CL & SH & CL+SH \\
\hline Water content $(\%)$ & $72.18 \pm 1.41^{\mathrm{ab}}$ & $70.74 \pm 1.51^{\mathrm{a}}$ & $74.02 \pm 1.25^{\mathrm{bc}}$ & $75.06 \pm 1.37^{\mathrm{c}}$ \\
Fat $(\%)$ & $7.61 \pm 0.35^{\mathrm{a}}$ & $8.00 \pm 1.86^{\mathrm{a}}$ & $7.54 \pm 0.44^{\mathrm{a}}$ & $7.12 \pm 0.46^{\mathrm{a}}$ \\
Glycogen $(\mathrm{mg} / 100 \mathrm{ml})$ & $0.15 \pm 0.04^{\mathrm{a}}$ & $0.11 \pm 0.01^{\mathrm{a}}$ & $0.15 \pm 0.04^{\mathrm{a}}$ & $0.11 \pm 0.02^{\mathrm{a}}$ \\
HSI $(\%)$ & $1.86 \pm 0.02^{\mathrm{a}}$ & $1.87 \pm 0.01^{\mathrm{ab}}$ & $1.90 \pm 0.01^{\mathrm{c}}$ & $1.89 \pm 0.01^{\mathrm{bc}}$ \\
\hline
\end{tabular}

Note: - The values listed were the mean and standard deviation

- Different superscripts on the same row indicated significant differences $(\mathrm{P}<0.05)$ 
Table 4 . The blood biochemistry of catfish after 60 days of the feeding trial.

\begin{tabular}{lcccc}
\hline \multirow{2}{*}{\multicolumn{1}{c}{ Parameters }} & \multicolumn{4}{c}{ Treatments } \\
\cline { 2 - 5 } & Control & CL & SH & CL+SH \\
\hline Triglyceride (mg/dL) & $416.00 \pm 55.34$ & $422.41 \pm 107.22$ & $446.74 \pm 61.88$ & $524.05 \pm 32.82$ \\
Cholesterol (mg/dL) & $143.76 \pm 3.53$ & $139.65 \pm 10.09$ & $144.79 \pm 13.94$ & $156.68 \pm 14.09$ \\
HDL (mg/dL) & $84.41 \pm 28.95$ & $98.09 \pm 13.01$ & $73.18 \pm 11.45$ & $103.70 \pm 19.45$ \\
\hline
\end{tabular}

Note: the values listed were the mean and standard deviation

control, ranged from 14.42 to $632.27 \mathrm{~g} /$ individual was not significantly different. This indicated that the experimental diets could be used by catfish. It was probably due to the use of vegetable and animal oil in formulated diets and the similarity in energy content of the diet influenced palatability of the diets. Although the feed intake values of catfish for all treatments were not significantly different from the control, the incorporation of CL in the diet might improve protein retention at a value of $20.7 \%$ compared to the control. Polyphenols contained in cinnamon leaves might increase the protein metabolism in catfish body. According to Takasao et al. (2012), cinnamaldehyde was able to activate the insulin-like growth factor (IGF-1), enhanced the biosynthesis of protein and collagen in the tissues of the body, thereby increasing the deposition of proteins in the body to build muscle. These results were in line with Setiawati et al. (2014) that the inclusion of $1 \%$ cinnamon leaves meal in the diet of catfish larvae increased $1.5 \%$ of the protein retention.

Polyphenol in cinnamon is considered to have similar activity to insulin (insulin mimesis). Polyphenol in cinnamon have similar activity to insulin called MHCP (methyl hydroxy chalcone polymers) that can increase insulin activity (Anderson et al., 2006). Insulin holds a crucial role in the metabolism of protein and fat. Similarly, protein retention value of the fish fed $\mathrm{CL}+\mathrm{SH}$ diets increased due to the addition of polyphenol, that found in chitin (shrimp heads). Chitin is identified to increase protein metabolism. Thus, more proteins can be retentive. Fall et al. (2012) stated that the use of shrimp head meal as a replacement for fish meal in tilapia feed within 60 days increased the protein content of the tilapia body. Similarly, Melati et al. (2012) reported that the fish fed $45 \%$ shrimp heads protein resulted in increased protein retention. The HSI (hepatosomatic index) results showed that CL was significantly different from $\mathrm{SH}$. However, the $\mathrm{CL}+\mathrm{SH}$ treatment was not significantly different from $\mathrm{CL}$ and $\mathrm{SH}$ treatments. It indicated that the active compounds in cinnamon leaves and shrimp head meal have a similar effect on the metabolism process in the liver. The energy reserved of catfish is generated from glycogen metabolism in liver and fat. Glycogen serves as a short term store, which is used quickly if sugar is available in blood or place others have been exhausted for energy needs (Setiawati et al., 2015). Furthermore, the amount of glycogen and fat increased the weight of catfish liver. Genten et al. (2009) stated that the liver has a very important role in protein synthesis, nutrient assimilation, the maintenance of body metabolism including the processing of carbohydrates, proteins, fats, and vitamins.

In this study, a higher fat retention was obtained in the fish fed CL diet than those of $\mathrm{CL}+\mathrm{SH}$. Nonetheless, both $\mathrm{SH}$ diet and $\mathrm{CL}+\mathrm{SH}$ diet were not significantly different. The results suggested that the shrimp head meal $(\mathrm{CL}+\mathrm{SH})$ could decrease $10.2 \%$ of fat retention in the fish body. When the shrimp head meal and cinnamon leaves were mixed in the same diet, fat retention decreased because of chitin, it considered as the main constituent substance in shrimp head meal and had high fibre contents. The largest source of fibre in control derived from bran, but it was not effective in binding fat in this study compared to cinnamon leaves and shrimp heads. As a result, the fat absorption into the body through the incoming feed was low. Nevertheless, when the fish fed SH diet, the catfish was more effective in utilizing the fat as energy source. In the other hand, when fish fed with CL diet, the catfish used carbohydrate as a source of energy for its activity as indicated by a higher value of fat retention.

However, the active compounds in the cinnamon leaves, such as cinnamaldehyde and polyphenol improved the metabolism due to the decreasing of the cholesterol level and increase HDL level at 139.65 and $98.09 \mathrm{mg} / \mathrm{dL}$, respectively. This was in line with Setiawati et al. (2016), the cinnamon treatments could attenuate cholesterol level and increase levels of HDL. Nonetheless, the cinnamon leaves extract in the fish feed could reduce the levels of cholesterol, triglycerides, and could increase HDL level than 
control. Mannan et al. (2014) reported that the content cinnamaldehyde has similar effects on insulin activity that can lower triglyceride levels. Sangal (2011) reported that MHCP (methyl hydroxy chalcone polymers) has several effects on others in stimulating autophosphorylation of the insulin receptor, increasing glucose uptake, glycogen synthesis, and increasing the activity of glycogen synthase in adipocytes cells, and reduce the activity of glycogen synthase kinase- $3 \beta$.

Active compounds, such as tannins, saponins, flavonoids, and cinnamaldehyde found in the cinnamon leaves (Shen et al., 2010). The cinnamon has been identified to increase the fat metabolism for the source of energy and the maintenance of the fish body. The amount of protein in the fish body is mainly used to construct new muscle tissue. The relationship between fat, protein, and carbohydrate are called protein sparing effect (NRC, 2011). In line with protein retention, specific growth rate (SGR) of the fish fed with CL was significantly different from control. However, it was not different from the fish fed with $\mathrm{CL}+\mathrm{SH}$ diet. This was in line with Ahmad et al. (2011), the diet supplemented with $1 \%$ of cinnamon leaves meal increased SGR at a value of $12 \%$ when compared to controls. Feeding using cinnamon leaves increased feed efficiency at a value $10 \%$ compared to control. It indicated that the feed taken by the fish positively support the growth performance of the fish. Similarly, Setiawati et al. (2016) noted that the inclusion of $1 \%$ cinnamon leaves meal in the diet improved feed efficiency $(43.85 \%)$ compared to control (29.95\%). In addition, Rolin et al. (2015) stated that the highest feed efficiency $(81.7 \%)$ was found in feed containing $1 \%$ cinnamon leaves extract and the efficiency decreased with the increasing of doses.

\section{CONCLUSION}

The inclusion of cinnamon leaves and shrimp heads in the fish diet increased $5.8 \%$ of growth, $10 \%$ of feed efficiency, $20.7 \%$ of protein retention, and decreased $10.2 \%$ of the fat retention compared to control.

\section{ACKNOWLEDGMENT}

The author expresses gratitude to the Ministry of Research, Technology, and Higher Education for the grant of Strategic Featured Research to Dr. Mia Setiawati No. 691/IT.3.11/PN/2016 through research and development to the community, Bogor Agricultural University.

\section{REFERENCES}

Anderson RA, Broadhurst CL, Polansky MM. 2006. Isolation and characterization of chalcone polymers from cinnamon with insulin-like biological activities. American Journal of Clinical Nutrition 84: 1432-1436.

Ahmad MH, El Mesallamy AMD, Samir F, Zahran F. 2011. Effect of cinnamon Cinnamomum zeylanicum on growth performance, feed utilization, whole-body composition, and resistance to Aeromonas hydrophila in Nile tilapia. Journal of Applied Aquaculture 23: 289-298.

[FAO] Food and Agriculture Organization. 2014. FAO globefish reports-pangasius: September 2014. http://www.globefish.org/pangasiusjunie-2014. [January 15, 2016].

Diop D, Fall J, Sagne M, Loum A, Ndong D, Diouf M, Sarr A, Ayessou N, Thiaw OT. 2013. Use of biochemically improved shrimp industry waste in fry tilapia (Oreochromis niloticus, Linnaeus 1758) diets: effects on growth performance and carcass composition. Journal of Biology and Life 4: 328-340.

Fall J, Tseng YT, Ndong D, Sheen SS. 2012. The effects of replacement of soybean meal by shrimp shell seal on the growth of hybrid tilapia (Oreochromis niloticus $\times$ Oreochromis aureus) reared under brackish water. International Journal of Fisheries and Aquaculture 4: 85-91.

Genten F, Terwinghe E, Danguy A. 2009. Atlas of fish histology. Brussel, Belgium: Department of Histology and Biopathology of Fish Fauna Laboratory of Functional Morphology Université Libre de Bruxelles (U.L.B). Science Publishers, Enfield, New Hampshire, USA

Gruenwald J, Freder J, Armbruester N. 2010. Cinnamon and health. Critical reviews in Food Science and Nutrition 50: 822-834.

Guo Z, Zhu X, Liu J, Han D, Yang Y, Lan Z, Xie S. 2012. Effects of dietary protein level on growth performance, nitrogen and energy budget of juvenile hybrid sturgeon, Acipenser baerii $9 \times$ A. gueldenstaedtii $\sigma^{\prime}$. Aquaculture 338: 89-95.

Mannan MA, Rupa BA, Azam MNK, Ahmed MN, Hasan MN. 2014. A quick review on antidiabetic plants and action of phytocemicals. International Journal of Advance Research 2: 227-249. 
Melati I, Nugraha A, Teguh, Suhenda N. 2012. Penentuan dosis subtitusi protein tepung kepala udang terhadap tepung ikan dalam pakan benih ikan patin Pangasius hypopthalmus. Prosiding Indoaqua-Forum Inovasi Teknologi Akuakultur. Makassar: Pusat Penelitian dan Pengembangan Perikanan Budidaya.

Muflihunna A, Mu'nisa A. 2010. Preparation chitosan from rubbish shrimp windu and effect cholesterol level in rabbit Oryctolagus cuniculus in vivo. Bionature 11: 14-17.

[NRC] Nutritional Research Council. 2011. Nutrient requirement of fish and shrimp. Washington DC, USA: National Academic Press.

Pamungkas BF. 2007. Effect of $\mathrm{HCl}$ and $\mathrm{NaOH}$ at various concentrations and processing time toward characteristic of chitin from white shrimp head shell. Jurnal Teknologi Pertanian 2: 64-69.

Research Center Laboratory for Biological Resources and Biotechnology. 2016. Hasil analisa proksimat kepala udang. Bogor: Lembaga Penelitian dan Pemberdayaan Masyarakat, Institut Pertanian Bogor (ID).

Rolin F, Setiawati M, Jusadi D. 2015. Evaluation of the addition of cinnamon Cinnamomum burmannii leaves extract in diet for growth performance of catfish Pangasianodon hypophthalmus Sauvage, 1878. Jurnal Iktiologi Indonesia 15: 201-208.

Sangal A. 2011. Role of cinnamon as beneficial antidiabetic food adjunct: a review. Pelagia Research Library 2: 440-450.
Setiawati M, Jusadi D, Marlinda S, Syafruddin, D. 2014. Effect of addition Cinnamomun burmanni leaf in the diet on the growth performance and nutrient composition of Pangasius hypopthalmus. Jurnal Ilmu Pertanian Indonesia 19: 80-84.

Setiawati M, Sakinah A, Jusadi D. 2015. growth and meat performance of Pangasianodon hypopthalmus which fed with Cinnamomum burmanni leaves enriched diet. Jurnal Akuakultur Indonesia 14: 171-178.

Setiawati M, Jusadi D, Laheng S, Suprayudi MA, Vinasyiam A. 2016 The enhancement of growth performance and feed efficiency of Asian catfish Pangasianodon hypophthalmus fed on Cinnamomum burmannii leaf powder and extract as nutritional supplementation. AACL Bioflux 9: 1301-1309.

Shen Y, Fukushima M, Ito Y, Muraki E, Hosono T, Seki T, Ariga T. 2010. Verification of the antidiabetic effects of cinnamon Cinnamomum zeylanicum using insulin-uncontrolled type 1 diabetic rats and cultured adipocytes. Bioscience, Biotechnology and Biochemistry 74: 2418-2425.

Takasao N, Tsuji-Naito K, Ishikura S, Tamura A, Akagawa M. 2012. Cinnamon extract promotes type I collagen biosynthesis via activation of IGF-I signaling in human dermal fibroblasts. Journal of Agricultural and Food Chemistry 60: 1193-1200.

Watanabe T. 1988. Fish Nutrition and Mariculture. Tokyo: Kanagawa International Fish Training Center. 